\title{
The Calculation Of ROE: Pedagogical Issues And Integrative Opportunities
}

Jeff Heinfeldt, Randolph College, USA

Denise Rindler, Wright State University, USA

\begin{abstract}
One of the most widely used measures of firm profitability and stockholder return is return-onequity (ROE). However, depending upon an individual firm's financial decisions (for example, dividend policy) and an analyst's assumptions used for the ROE calculation, the results can vary significantly. This variation can create confusion for students when the topics of ratio and financial statement analysis are presented. This paper seeks to clarify these issues, offers suggestions to improve the topic discussion in the classroom, and provides examples of additional opportunities for interdisciplinary application.
\end{abstract}

Keywords: Return-on-Equity (ROE), Financial Pedagogy/Education, Interdisciplinary Integration

\section{INTRODUCTION}

(๑)

ne of the most widely used measures of firm profitability and stockholder return is return-on-equity (ROE). However, depending upon an individual firm's financial decisions (for example, dividend policy) and an analyst's assumptions used for the ROE calculation, the results can vary significantly. This variation can create confusion for students when the topics of ratio and financial statement analysis are presented. For example, the most commonly used formula for calculating ROE is:

$\mathrm{ROE}=$ annual net income

end-of-year common stockholder's equity

Where: common stockholder's equity consists of common stock + retained earnings

This method understates a firm's return to shareholders if all, or some, of the net income is retained. The analyst is dividing the return (net income for the year) by a figure (common stockholder's equity) that contains (a portion of) the net income for the current year in the retained earnings account.

\section{DISCUSSION AND ILLUSTRATION}

In an attempt to be accurate and consistent with other financial rate of return calculations, this paper proposes that a more effective approach would be to use beginning-of-year stockholder's equity when presenting and discussing a financial performance measure such as ROE in the classroom. This approach is particularly helpful due to the impact dividend policy can have on the calculation of ROE.

As the following example will illustrate, ROE is different between a dividend paying firm (100\% payout) and a non-dividend payer if using end-of-year equity. The assumptions are:

1. It is a 1-year time horizon.

2. Net Income is in cash.

3. Both firms are $100 \%$ equity financed, begin the year with $\$ 1000$ of contributed capital (common stock), and generate $\$ 100$ of net income with it (10\% rate of return). 
4. The dividend is paid annually (at year-end). Thus, both firms could reinvest the earnings during the year. However, for simplicity, it is assumed that earnings are not reinvested during the year. Rather, the net income is held in cash until the end of the year. At year-end, it is either reinvested (Company A) or paid out as a dividend (Company B).

The results are:

Company A, Year 1: $\$ 1000$ beginning equity, net income $=\$ 100$, no dividend.

$\mathrm{ROE} w /$ beginning equity $=100 / 1000=10 \%$

$\mathrm{ROE} w /$ ending equity $\quad=100 / 1100=9.1 \%$

Company B, Year 1: $\$ 1000$ beginning equity, net income $=\$ 100$, payout $100 \%$.

ROE $w /$ beginning equity $=100 / 1000=10 \%$

ROE w/ ending equity $=100 / 1000=10 \%$

Interestingly enough, it is often intuitive to the students that the two firms have had identical financial performance in terms of profitability and return to shareholders. Yet, the traditional ROE calculation may actually confuse them by indicating that one performed better than the other. From identical starting points, both firms produced $\$ 100$ of net income (equal profitability) and each provided a return to shareholders of $10 \%$. This can be seen by the following analysis:

For the dividend paying firm, it is clear that the annual holding period rate of return on the owners' invested capital (equity) for the first year was $10 \%$ (\$100 dividend on a $\$ 1000$ equity investment) assuming no change in stock (equity) value. Based on the relationship that total stockholder return consists of dividend yield and/or capital gain (i.e. $r_{s}=D Y+g$ ) and assuming the firm pays out $100 \%$ of earnings (no growth), then the investors receive this return as dividend yield $(\$ 100 / \$ 1000=10 \%)$. For the non-dividend paying firm, the return on invested capital (equity) for the owners is also 10\% for the first year. The difference is that the investors receive their return as capital gain (no dividend yield). This is reflected in the higher retained earnings and theoretically an increase of $\$ 100$ in equity valuation (capital gain).

At this point, in order to reconcile and confirm the equivalent financial performance of the two firms as measured by ROE, beginning-of-the-year equity needs to be used for the calculations. Otherwise, if the traditional "end-of-year equity" method is used for the ROE calculations, a student would obtain two different answers $(\$ 100 / \$ 1000=10 \%$ vs. $\$ 100 / \$ 1100=9.1 \%)$ when it is clear from the above discussion that the more accurate and consistent answer is $10 \%$. With respect to fundamental, financial performance, it is apparent to the students that the two firms have performed equally well. However, the ROE calculations have complicated matters for them. In addition, students recognize (in this particular situation) that a firm which retains net income can be "penalized" in terms of ROE but could "improve" its perceived financial performance (ROE) by paying a dividend thereby reducing its ending equity balance.

When calculating ROE, some texts and analysts have used an average equity value approach [(beginning of year equity + end of year equity)/2] to compensate for the fact that net income is earned throughout the year whereas the traditional year-end equity value in the ratio does not reflect the same activity (Brigham and Houston, 2004, p. 88). This approach still includes part of the year's net income in the denominator (equity value) for the non-dividend paying firm. For example:

$(\$ 1000$ beginning equity $+\$ 1100$ ending equity $) / 2=\$ 1050$

$\mathrm{ROE}=\$ 100$ net income $/ \$ 1050$ equity $=9.52 \%$ students:

While this modification attempts to address the timing issue, it clearly creates two other complications for

1. The "average" approach still generates an ROE for the non-dividend payer that is different than the $100 \%$ payout firm even though the students can see that the investors in both firms earned $10 \%$ on their contribution. 
2. It produces a third ROE for the non-dividend paying firm $(\$ 100 / \$ 1000=10 \%, \$ 100 / \$ 1100=9.1 \%$, $\$ 100 / \$ 1050=9.52 \%)$. Which ROE is “correct"?

It should also be noted that this modification moves the "revised" ROE of $9.52 \%$ closer to the preferred $10 \%$ figure. It appears that using the beginning-of-year equity balance, as opposed to end-of-year or average equity values, produces a more accurate, consistent, and intuitive result for ROE particularly when taking dividend policy into account.

This analysis, combined with the intention to be consistent when calculating rate of return, can be carried over into other financial areas such as banking. For instance, a depositor invests $\$ 1000$ in a one-year certificate of deposit (CD) at a bank. The CD earns $10 \%$ per year compounded annually. The interest (\$100) may be received as a check or compounded back onto the account. If the depositor chooses to receive the interest check at year-end, the individual will have a $\$ 1000 \mathrm{CD}$ and $\$ 100$ cash. The rate of return will have been $10 \%$ (Note: This is comparable to the "dividend" paying firm above). If the depositor chooses to have the interest compounded back onto the account, the individual will end the year with a CD worth $\$ 1100$ and will have also had a $10 \%$ rate of return (Note: This is comparable to the "non-dividend" paying firm above). For the compounding alternative, it is clear that the rate of return was determined by dividing income $(\$ 100)$ by the beginning investment amount $(\$ 1000)$. In other words, the rate of return under the compounding alternative was not determined by dividing the income by the ending value $(\$ 100 / \$ 1100=9.1 \%)$, which is the methodology of the traditional ROE calculation. In addition, the rate of return with compounding is not calculated by using the "average" account balance for the denominator $(\$ 100 / \$ 1050=$ $9.52 \%)$.

An important point here, with respect to student application and comprehension, is that in either case the depositor earned $\$ 100$ (income) on an investment of $\$ 1000$ (similar to the ROE example at the beginning of the paper). The bank would indicate a rate of return of $10 \%$, not $9.1 \%$ or $9.52 \%$. Based on the analysis and illustrations provided, it would seem that for consistency and clarity, a better method for calculating ROE would be to use the beginning equity balance as opposed to the ending balance.

\section{INTERDISCIPLINARY OPPORTUNITIES}

Porter and McKibbin (1988) are generally credited with initially discussing the importance of an integrated business curriculum. In turn, external constituents such as employers and accreditation agencies have suggested that students should be able to integrate ideas and processes across the various functional disciplines. This is particularly the case as students prepare for working in teams upon entering the professional environment. Supporters and proponents of functional-area integration and interdisciplinary exercises suggest potential benefits may include:

1. Increased student exposure to the integrative nature of business decisions and the manner in which each functional area fits within the larger organization (Heggen, 2008).

2. Enhanced student preparation and qualification for employment opportunities (e.g. teamwork and integration) (Athavale, Davis, and Myring, 2008; Hamilton, McFarland, and Mirchandani, 2000; Pharr, 2000; Stover, Morris, Pharr, Reyes, and Byers, 1997).

3. Expanded knowledge base (and "enlightenment") for faculty (Bishop, Vaughan, Jensen, Hanna, and Graf, 1998). In particular, the opportunity is available for faculty to incorporate additional interdisciplinary content into their preparation and course materials (Aurend, DeMoranville, and Gordon, 2001).

4. Increased support and encouragement from constituents/stakeholders such as employers, advisory boards, and accreditors (Athavale et al., 2008; Aurend et al., 2001; Barber, Borin, Cerf, and Swartz, 2001; Heggen, 2008; Pharr, 2000; Stover et al., 1997)

5. Addressing student expectations regarding integration and interdisciplinary discussions. Students are aware that organizations operate cross-functionally and appreciate the exposure to these examples (Aurend et al., 2001).

Given these potential benefits, if an instructor is seeking a classroom activity or topic with integrative aspects, this discussion regarding the calculation of ROE provides an ideal opportunity for areas such as finance, accounting, and economics. For example, opportunities for integration include: 
1. In Finance: Review of accounting concepts such as the closing of net income to retained earnings, declare/pay dividend, financial statements, etc.

2. In Accounting: Discuss stockholders equity (owners of the firm), capital structure (debt \& equity), the distribution to shareholders (dividends) and retention (capital gain) trade-off, etc.

3. In Economics (Money \& Banking and Financial Markets \& Institutions): Discuss return-on-equity (ROE) and similarly return-on-investment (ROI), capital gain and dividend yield, the cash payment (distribution) of return from a financial instrument (such as interest and dividends) versus compounding (retaining) the returns (cash), etc.

While the interdisciplinary and integrative opportunities briefly described above are not very elaborate or involved, the discussions are very effective and can be done quickly and easily as part of regular course content and discussion. It should be made clear: this paper is in no way a call for a complete curricular overhaul resulting in a fully integrated business program. Rather, the discussion of this particular topic (ROE calculation) also happens to provide a relatively simple, straightforward analysis from which an instructor can integrate, review, and reinforce concepts from various functional area courses.

\section{CONCLUSION}

This paper examines several methods for calculating return-on-equity (ROE) and provides a number of quantitative examples. The examples are used to illustrate the difficulties, complications, and uncertainties students may encounter in interpreting the results. A pedagogical suggestion, along with the assumptions employed, is made in an effort to improve both the calculation method and classroom discussion. Finally, opportunities for integrating the topic across several functional disciplines are discussed.

\section{AUTHOR INFORMATION}

Jeff Heinfeldt earned his Ph.D. at Kent State University in 1995. Currently he is an associate professor of economics/business at Randolph College.

Denise Rindler is a strategic sourcing analyst at Wright State University.

\section{REFERENCES}

1. Athavale, M., R. Davis, and M. Myring, The Integrated Business Curriculum: An Examination of Perceptions and Practice, Journal of Education for Business, Vol. 83, No. 5, pp. 295-301, 2008.

2. Aurand, T.W., C. DeMoranville, and G.L. Gordon, Cross-Functional Business Programs: Critical Design and Development Considerations, Mid-American Journal of Business, Vol. 16, No. 2, pp. 21-30, 2001.

3. Barber, C. S., N. Borin, D.C. Cerf, and T.A. Swartz, The Role of Marketing in an Integrative Business Curriculum, Journal of Marketing Education, Vol. 23, No. 3, pp. 240-248, 2001.

4. Bishop, T. R., R. Vaughan, G. Jensen, N. Hanna, and D.A. Graf, Cross-Functionally Integrated Undergraduate Business Core Curriculum, Mid-American Journal of Business. Vol. 13, No. 1, pp. 65-71, 1998.

5. Brigham, E. and J. Houston, Financial Management: Concise $4^{\text {th }}$ edition, Thomson-SouthWestern, Mason, $\mathrm{OH}, 2004$.

6. Hamilton, D., D. McFarland, and D. Mirchandani, A Decision Model for Integration across the Business Curriculum in the 21st Century, Journal of Management Education, Vol. 24, No. 1, pp, 102-126, 2000.

7. Heggen, J., De-Departmentalizing the B-School, Inside Higher Ed., www.insidehighered.com /news/2008/06/02/villanova, June, 2008.

8. Pharr, S.W., Foundational Considerations for Establishing an Integrated Business Common Core Curriculum, Journal of Education for Business, Vol. 76, No. 1, pp. 20-23, 2000.

9. Porter, L. and L. McKibbin, Management Education and Development: Drift or Thrust into the $21^{\text {st }}$ Century? McGraw-Hill, New York, 1988.

10. Stover, D., J.S. Morris, S. Pharr, M.G. Reyes, and C.R. Byers, Breaking Down the Silos: Attaining an Integrated Business Common Core, American Business Review, Vol. 15, No. 2, pp. 1-11, 1997. 